\title{
Tracking of cellular atypes of the cut of uterus of women in Primary Care
}

\author{
Rastreamento das atipias celulares de colo de útero em mulheres na Atenção Primária \\ Detección de las atipias celulares del cuello uterino en mujeres en la Atención Primaria
}

Jamile Mika Yoshikawa Kurebayashi' ORCID: 0000-0003-1585-2030

Márcia Barbieri' ORCID: 0000-0002-4662-1983

Maria Cristina Gabrielloni' ORCID: 0000-0003-2395-9161

'Universidade Federal de São Paulo. São Paulo, São Paulo, Brazil.

How to cite this article: Kurebayashi JMY, Barbieri M, Gabrielloni MC. Tracking of cellular atypes of the cut of uterus of women in Primary Care. Rev Bras Enferm. 2020;73(Suppl 6):e20190753. doi: http://dx.doi.org/10.1590/0034-7167-2019-0753

\section{Corresponding author:} Jamile Mika Yoshikawa Kurebayashi E-mail: jamile.mika@yahoo.com.br

EDITOR IN CHIEF: Dulce Barbosa ASSOCIATE EDITOR: Ana Fátima Fernandes

Submission: 01-09-2020

Approval: 07-04-2020

\section{ABSTRACT}

Objectives: to analyze the screening for cervical cell atypias in women assisted in Primary Care. Methods: quantitative, retrospective and cross-sectional study, with analysis of 190 medical records of women who had atypical results from the cervical cytopathological exam collection from 2012 to 2014. Results: the most frequent atypias found were possibly Nonneoplastic squamous (ASC-US, 57.4\%) and Low-grade intraepithelial lesion (LSIL, 23.2\%). The time elapsed between the exam and the result was 24 days. The professional's conduct after the result of the last cervical cytopathology was adequate for $51.1 \%$ of women. Conclusions: there is a need to improve the cervical cancer screening program and correctly target the atypia identified, aiming at the access of the target population for the diagnostic investigation and treatment of precursor lesions of cervical cancer.

Descriptors: Cervical Intraepithelial Neoplasia; Mass Screening; Uterine Cervical Dysplasia; Primary Health Care; Health Promotion.

\section{RESUMO}

Objetivos: analisar o rastreamento das atipias celulares de colo de útero em mulheres assistidas na Atenção Primária. Métodos: estudo quantitativo, retrospectivo e transversal, com análise de 190 prontuários de mulheres que apresentaram atipias no resultado da coleta de exame citopatológico cervical no período de 2012 a 2014. Resultados: as atipias mais frequentes encontradas foram Escamosas possivelmente não neoplásicas (ASC-US, 57,4\%) e Lesão intraepitelial de baixo grau (LSIL, 23,2\%). 0 tempo transcorrido entre a realização do exame e a chegada do resultado foi de 24 dias. A conduta do profissional após o resultado da última citopatologia cervical foi adequada para $51,1 \%$ das mulheres. Conclusões: há necessidade de aprimorar o programa de rastreamento de câncer de colo do útero e de direcionar corretamente as atipias identificadas, visando ao acesso da população-alvo para a investigação diagnóstica e tratamento das lesões precursoras do câncer de colo uterino. Descritores: Neoplasia Intraepitelial de Colo do Útero; Programas de Rastreamento; Displasia do Colo do Útero; Atenção Primária de Saúde; Promoção da Saúde.

\section{RESUMEN}

Objetivos: analizar la detección de las atipias celulares del cuello uterino en mujeres asistidas en la Atención Primaria. Métodos: estudio cuantitativo, retrospectivo y transversal, con análisis de 190 historias clínicas de mujeres que presentaron atipias en el resultado de la recogida de examen histopatológico cervical en el período de 2012 a 2014. Resultados: las atipias más frecuentes encontradas han sido Escamosas posiblemente no neoplásicas (ASC-US, 57,4\%) y Lesión intraepitelial de bajo grado (LSIL, 23,2\%). El tiempo transcurrido entre la realización del examen y la llegada del resultado ha sido de 24 días. La conducta del profesional después del resultado de la última citopatología cervical ha sido adecuada para $51,1 \%$ de las mujeres. Conclusiones: hay necesidad de perfeccionar el programa de detección del cáncer del cuello uterino y de orientar correctamente las atipias identificadas, visando al acceso de la población objetivo para la investigación diagnóstica y tratamiento de las lesiones precursoras del cáncer de cuello uterino.

Descriptores: Neoplasia Intraepitelial de Cuello Uterino; Programas de Detección; Displasia del Cuello Uterino; Atención Primaria de Salud; Promoción de la Salud. 


\section{INTRODUCTION}

Cancer is a leading cause of death worldwide ${ }^{(1)}$. In Brazil, in the 2018-2019 biennium, it was estimated that 600 thousand new cases of cancer occur each year ${ }^{(2)}$. Cervical cancer is one of the most serious threats to women's lives. About a million women suffer from the disease in the world, and most of them are in underdeveloped and developing countries $^{(3)}$.

In general, cervical cancer (CC) starts from the age of 30, increasing its risk quickly until reaching its peak age, between 50 and 60 years. In our country, this pathology has progressively affected a larger number of women in increasingly younger age groups and with an increasing mortality rate ${ }^{(4)}$.

Considered as a progressive disease, the CC is characterized by cervical intraepithelial changes, which can develop to an invasive stage over one to two decades. Its characteristic is the disordered replication of the organ lining epithelium, compromising the underlying tissue (stroma), which can invade contiguous or distant structures and organs ${ }^{(5)}$.

There are two main categories of invasive carcinomas of the cervix, depending on the origin of the compromised epithelium: squamous cell carcinoma, the most incident type and affecting the squamous epithelium, which represents about $80 \%$ of the cases; and adenocarcinoma, a rarer type that affects the glandular epithelium. Because of its well-defined and slow evolution stages, cervical cancer allows its interruption from an early diagnosis and timely treatment at reduced costs ${ }^{(6)}$.

Currently, $44 \%$ of cases are precursor lesions of cancer, called in situ, considered localized. Women diagnosed early, with proper treatment, have almost $100 \%$ chance of being cured $^{(7)}$.

For the screening of cervical cancer, Brazil adopts the Pap smear technique, offered in the public and private service to women who have active and non-active sex lives, as well as women in menopause, those who have undergone partial hysterectomy and are pregnant ${ }^{(6)}$.

Despite primary and secondary prevention measures, cervical cancer continues to have high rates of incidence and mortality, especially in countries with low and medium income per capita ${ }^{(8)}$.

Considering the importance of CC prevention to reduce its incidence and mortality among women in our country, it is essential that health and operational actions are directed to a screening program capable of guaranteeing access and treatment whenever necessary.

\section{OBJECTIVES}

To analyze the screening for cervical cell atypias in women assisted in Primary Care.

\section{METHODS}

\section{Ethical aspects}

The development of the study complied with national standards for research involving human beings, since, prior to data collection, it was submitted to the Municipal Health Secretariat of São Paulo, at the Regional Health Coordination North, and to the
Research Ethics Committee of the university to which it is related.

\section{Study type and location}

Quantitative, retrospective and cross-sectional study prepared according to the guidelines of the Strengthening the Reporting of Observational Studies in Epidemiology $(\mathrm{STROBE})^{(9)}$, carried out in a Basic Health Unit (BHU) located in the northern region of the city of São Paulo. It is a mixed unit consisting of two distinct assistance models, called traditional BHU and BHU Family Health Strategy (FHS).

Women registered in the traditional $\mathrm{BHU}$ assistance model are assisted by specialist doctors in the area of obstetrics and gynecology and by nurses who provide free-demand care from the user's demand for assistance; and those registered in the FHS assistance model are assisted by general practitioners and a family health nurse, in medical and/or nursing consultation. The FHS model aims to be proactive in identifying the problems in the health-disease process, through the registration and continuous and comprehensive monitoring of users and their families inserted in a community defined by territorial limits.

\section{Population, sample, period, eligibility criteria}

The population consisted of 5,996 records of women assisted in the referred $\mathrm{BHU}$, with 2,675 (44.6\%) records of the traditional care model and 3,321 (55.4\%) of the FHS care model, from February 2012 to December 2014.

The study included women aged 14 years and over who resided in the area covered by the Technical Health Supervision of the northern region of the city of São Paulo and who underwent cytopathological screening by means of a smear stained by the Pap smear during that period. The choice for age was solely due to the fact that, from the age of 14 onwards, the search for health care services for women arising from gynecological complaints begins. No exclusion criteria were used. The option to cut time was based on the availability of medical records by BHU management. The sample was obtained after analyzing the reports present in the 5,996 medical records. Thus, it was composed of 190 medical records of women assisted at BHU who presented a record of cell atypias, corresponding to $3.2 \%$ of the assisted population. Of these, 91 belonged to the Traditional model and 99 to the FHS, with cervical cell atypias as a result of the cervical cytopathological exam collection during the studied period.

\section{Study variables}

The studied variables were stratified in sociodemographic and related to the collection of the cytological exam; time between taking the exam and the result and consultation; cytological examination results. The atypias were evaluated and classified according to the Brazilian Nomenclature for Cervical Cytopathological Reports of the National Cancer Institute (INCA)/Ministry of Health (MS) ${ }^{(10)}$, such as: Atypical Cells of Undetermined Significance (Possibly Non-Neoplastic Squamous [ASC-US], High-Grade Squamous Intraepithelial Lesion cannot be ruled out [ASC-H], Glandular Possibly Non-Neoplastic and Glandular 
in which High-Grade Intraepithelial Lesion cannot be ruled out [AGC]), Atypias in Squamous Cells (Low-Grade Intraepithelial Lesion, comprising HPV and NIC grade I LSIL cytopathic effect and High-Grade Intraepithelial Lesion including NIC grades II and III HSIL) and Atypias in Glandular Cells.

The analysis of the conduct of the professionals responsible for the collection is performed after atypia evaluation in the cytological exam. For that, the recommended Guidelines for Cervical Cancer Screening of the MS and INCA were considered, which considers the repetition of the exam in six months in the Atypias of Undetermined Significance in Possibly Non-Neoplastic Squamous Cells (ASC-US) or Low-Grade Intraepithelial Lesion (LSIL); colposcopy request in Atypias of Undetermined Significance in High-Grade Epithelial Lesion, Squamous Cells in which High-Grade Lesion cannot be ruled out (ASC-H), Glandular Cells (AGC), as well as in High-Grade Intraepithelial Lesion (HSIL). As not adequate, it considers any and all conduct that is different from those recommended by the Guidelines for the Screening of Cervical Cancer ${ }^{(11)}$.

\section{Data analysis}

To simultaneously assess the effects of potential factors associated with the type of conduct received by the service user according to the "adequate" or"not adequate" guidelines, logistic regression was used. The existence of associations between two categorical variables was verified using the chi-square test or, alternatively, in cases of small samples, of Fisher's exact test. The comparison of means between two groups was performed using the Student's $t$ test for independent samples. For the analysis of all statistical tests, a significance level of $5 \%$ was considered, with the computational support of the software IBM SPSS 20.0 Statistical Package for the Social Sciences, Stata 12 and Excel 2016 (Microsoft Office ${ }^{\circ}$ ).

\section{RESULTS}

It was observed that women were also assisted by the traditional BHU and the FHS model $(p=0.320)$. It was found that, at least once a year, $33.7 \%$ of them had a medical consultation; and $30.5 \%$, nursing consultation on women's health. Additionally, $65.3 \%$ had one year between the Pap smear exams, $61.6 \%$ of which were performed by nurses.

The results revealed that $57.4 \%$ of women with some cervical cell atypia were of Undetermined Siginificance in Possibly Non-Neoplastic Squamous Cells (ASC-US); and 23.2\%, Low-Grade Squamous Intraepithelial Lesion (LSIL). However, Atypias of Undetermined Siginificance in Squamous Cells (ASC-H) and Atypias of Undetermined Siginificance in Glandular Cells (AGC) in which High-Grade Lesion cannot be ruled out and High-Grade Squamous Intraepithelial Lesion (HSIL) were low, lower at 5\% (Table1).

As for the conduct of the professional responsible for the collection, it was observed that $51.1 \%$ of women received adequate conduct after the result of the last cervical cytopathology. However, $41 \%$ received inappropriate conduct and $7.9 \%$ did not receive any conduct. It was found that, on average, women who received adequate conduct had a shorter time between the examination and the arrival of the result at $\mathrm{BHU}$ (average of 25 days) compared to those who received inappropriate conduct (average of 29 days). However, there was no statistically significant difference $(p=0.046)$ (Table 2$)$.

After knowledge of the altered examination result, the adequacy of the conduct received by the women regarding the recommendations of the MS was assessed. Among the appropriate conducts, it was considered, in $67.9 \%$, to repeat the exam in six months in Atypias of Undetermined Significance in Possibly Non-Neoplastic Squamous Cells (ASCUS) and in 13.6\% in cases of Low-Grade Intraepithelial Lesion (LSIL). The results found also reveal that, in $50 \%$ of the Atypia of Undetermined Significance in High-Grade Epithelial Lesion, Squamous Cells in which High-Grade Lesion cannot be ruled out (ASC-H) and in $45.5 \%$ of Glandular Cells (AGC), there was a conduct considered adequate, related to the request for the colposcopy exam (Table 3).

When considering as final outcome the association between the conduct and the result of the last cervical cytopathology as the final outcome, it was observed that women diagnosed with ASC-US had a higher percentage of follow-up through the annual gynecological routine (51.3\%) compared to women with ASC - H $(0 \%)$ and HSIL (0\%). In the semi-annual gynecological routine, women with ASC-H had a higher percentage of follow-up (75.0\%). However, the number of women who abandoned follow-up is noteworthy (Table 4).

The association between the professional's conduct and the result of the last cervical cytopathology was verified $(p<0.001)$. Thus, it was identified that the group of users with ASC-US had a higher percentage of adequate referrals performed by the professional who assisted them (67.9\%) (Table 5).

Table 1 - Distribution of women as a result of the last cervical cytopathology and respective 95\% confidence intervals, São Paulo, São Paulo, Brazil, 2014

\begin{tabular}{|c|c|c|}
\hline Variable & n (\%) & $\begin{array}{c}95 \% \\
\text { confidence } \\
\text { interval }\end{array}$ \\
\hline
\end{tabular}

Total

$190(100.0 \%)$

ASC-US: Atypical cells of

undetermined significance, possibly

$109(57.4 \%)$

$(50.0 \%-64.5 \%)$ non-neoplastic, squamous

ASC-H: Atypical cells of undetermined significance, squamous in which a high-grade lesion cannot be ruled out

$$
8(4.2 \%) \quad(1.8 \%-8.1 \%)
$$

AGC: Atypical cells of undetermined significance, possibly non-neoplastic glandular cells

$22(11.6 \%) \quad(7.4 \%-17.0 \%)$

AGC: Atypical cells of undetermined significance, glandular in which a high-grade lesion cannot be ruled out

$1(0.5 \%) \quad(0.0 \%-2.9 \%)$

LSIL: Squamous cell atypias,

low-grade intraepithelial lesion (comprising HPV cytopathic effect and grade I cervical intraepithelial neoplasia)

HSIL: Atypias in squamous cells, high-grade intraepithelial lesion (comprising grade II and III cervical intraepithelial neoplasms) 
Table 2 - Time between collection and result and time between collection and consultation by type of conduct, São Paulo, São Paulo, Brazil, 2014

\begin{tabular}{|c|c|c|c|c|c|c|c|c|c|}
\hline Variable & Mean & Standard deviation & Minimum & Maximum & $\mathbf{1}^{\text {st }}$ Quartile & Median & $3^{\text {rd }}$ Quartile & $\mathbf{n}$ & $p$ \\
\hline $\begin{array}{l}\text { Time between taking the exam and } \\
\text { arriving at } \mathrm{BHU} \text { (days) }\end{array}$ & 27.5 & 12.9 & 11.0 & 89.0 & 20.0 & 25.0 & 30.0 & 175 & \multirow{3}{*}{0.046} \\
\hline Adequate & 25.7 & 11.2 & 11.0 & 80.0 & 19.0 & 23.0 & 28.5 & 97 & \\
\hline Not adequate & 29.7 & 14.6 & 13.0 & 89.0 & 20.0 & 27.0 & 33.0 & 78 & \\
\hline $\begin{array}{l}\text { Time between taking the exam and } \\
\text { consulting at BHU (months) }\end{array}$ & 2.9 & 2.1 & 1.0 & 12.0 & 2.0 & 2.0 & 3.0 & 175 & \multirow{3}{*}{0.124} \\
\hline Adequate & 3.1 & 2.4 & 1.0 & 12.0 & 2.0 & 2.0 & 4.0 & 97 & \\
\hline Not adequate & 2.6 & 1.7 & 1.0 & 9.0 & 2.0 & 2.0 & 3.0 & 78 & \\
\hline
\end{tabular}

Note: $p$-Descriptive level of Student's $t$-test; $B H U$-Basic Health Unit.

Table 3 - Adequacy of medical management after evaluation of cervical cytopathology results, São Paulo, São Paulo, Brazil, 2014

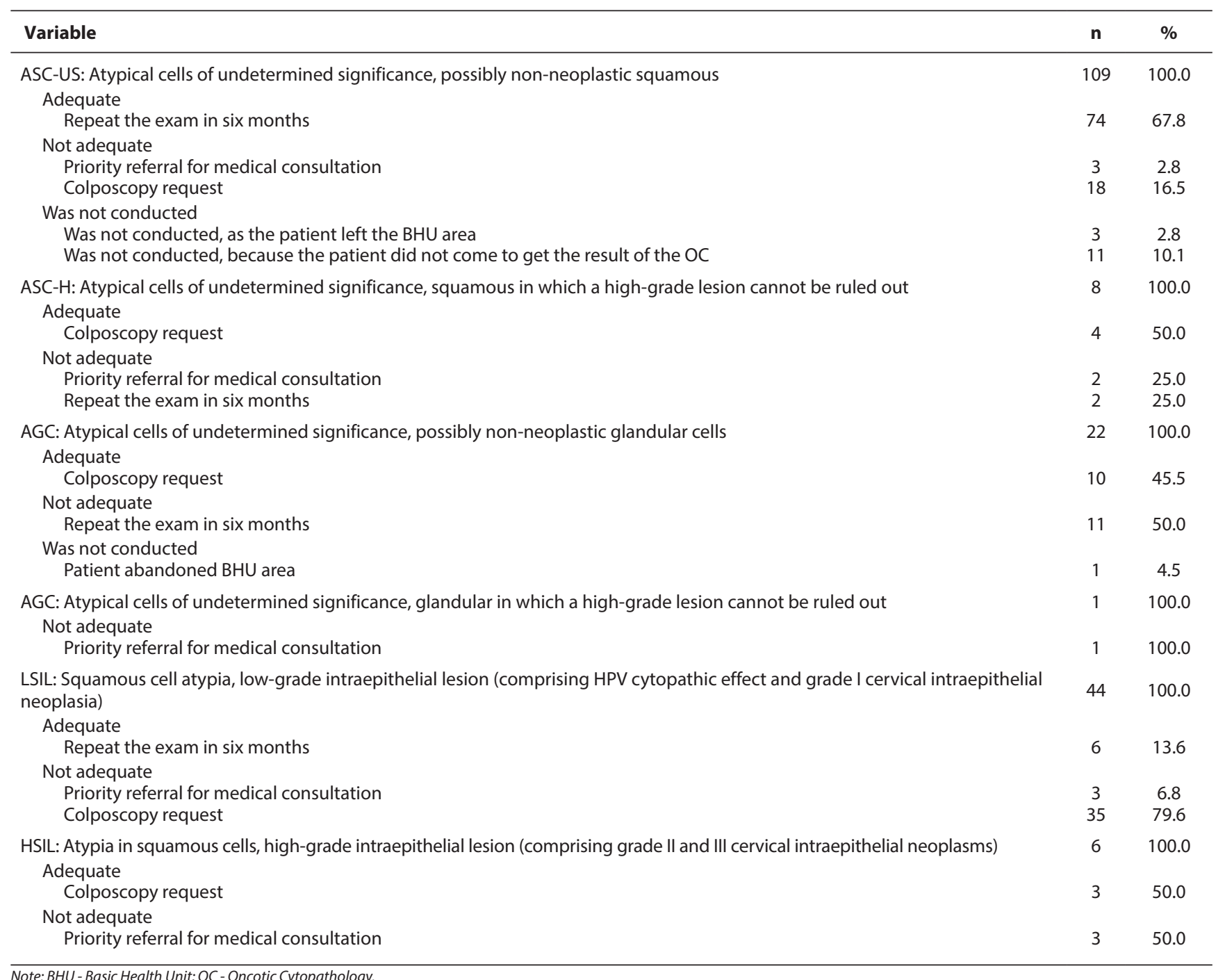

Table 4 - Final conduct, according to the result of the last cervical cytopathology, São Paulo, São Paulo, Brazil, 2014

\begin{tabular}{|c|c|c|c|c|c|c|c|c|c|c|}
\hline \multirow{3}{*}{ Variable } & \multicolumn{8}{|c|}{ Final outcome } & \multirow{2}{*}{\multicolumn{2}{|c|}{ Total }} \\
\hline & \multicolumn{2}{|c|}{$\begin{array}{c}\text { Annual gynecological } \\
\text { routine }\end{array}$} & \multicolumn{2}{|c|}{$\begin{array}{l}\text { Semi-annual Semester } \\
\text { gynecological routine }\end{array}$} & \multicolumn{2}{|c|}{$\begin{array}{l}\text { In high-risk } \\
\text { treatment }\end{array}$} & \multicolumn{2}{|c|}{$\begin{array}{l}\text { Abandonment of } \\
\text { treatment }\end{array}$} & & \\
\hline & $\mathbf{n}$ & $\%$ & $\mathbf{n}$ & $\%$ & $\mathbf{n}$ & $\%$ & $\mathbf{n}$ & $\%$ & $\mathbf{n}$ & $\%$ \\
\hline Result of the last cervical cytopathology & 76 & $40.0 \%$ & 66 & $34.7 \%$ & 10 & $5.3 \%$ & 38 & $20.0 \%$ & 190 & $100.0 \%$ \\
\hline $\begin{array}{l}\text { ASC-US: Atypical cells of undetermined } \\
\text { significance, possibly non-neoplastic, } \\
\text { squamous }\end{array}$ & 56 & $51.3 \%$ & 26 & $23.9 \%$ & 3 & $2.8 \%$ & 24 & $22.0 \%$ & 109 & $100.0 \%$ \\
\hline
\end{tabular}




\begin{tabular}{|c|c|c|c|c|c|c|c|c|c|c|}
\hline \multirow{3}{*}{ Variable } & \multicolumn{8}{|c|}{ Final outcome } & \multirow{2}{*}{\multicolumn{2}{|c|}{ Total }} \\
\hline & \multicolumn{2}{|c|}{$\begin{array}{c}\text { Annual gynecological } \\
\text { routine }\end{array}$} & \multicolumn{2}{|c|}{$\begin{array}{l}\text { Semi-annual Semester } \\
\text { gynecological routine }\end{array}$} & \multicolumn{2}{|c|}{$\begin{array}{l}\text { In high-risk } \\
\text { treatment }\end{array}$} & \multicolumn{2}{|c|}{$\begin{array}{c}\text { Abandonment of } \\
\text { treatment }\end{array}$} & & \\
\hline & $\mathbf{n}$ & $\%$ & $\mathbf{n}$ & $\%$ & $\mathbf{n}$ & $\%$ & $\mathbf{n}$ & $\%$ & $\mathbf{n}$ & $\%$ \\
\hline $\begin{array}{l}\text { ASC-H: Atypical cells of undetermined } \\
\text { significance, squamous in which a high- } \\
\text { grade lesion cannot be ruled out }\end{array}$ & 0 & $0.0 \%$ & 6 & $75.0 \%$ & 2 & $25.0 \%$ & 0 & $0.0 \%$ & 8 & $100.0 \%$ \\
\hline $\begin{array}{l}\text { AGC: Atypical cells of undetermined } \\
\text { significance, possibly non-neoplastic } \\
\text { glandular cells }\end{array}$ & 8 & $36.4 \%$ & 7 & $31.8 \%$ & 0 & $0.0 \%$ & 7 & $31.8 \%$ & 22 & $100.0 \%$ \\
\hline $\begin{array}{l}\text { AGC: Atypical cells of undetermined } \\
\text { significance, glandular in which a high- } \\
\text { grade lesion cannot be ruled out }\end{array}$ & 0 & $0.0 \%$ & 0 & $0.0 \%$ & 1 & $100.0 \%$ & 0 & $0.0 \%$ & 1 & $100.0 \%$ \\
\hline $\begin{array}{l}\text { LSIL: Atypia in squamous cells, low- } \\
\text { grade intraepithelial lesion } \\
\text { (comprising HPV cytopathic effect and } \\
\text { grade I cervical intraepithelial neoplasia) }\end{array}$ & 12 & $27.3 \%$ & 26 & $59.0 \%$ & 1 & $2.3 \%$ & 5 & $11.4 \%$ & 44 & $100.0 \%$ \\
\hline $\begin{array}{l}\text { HSIL: Atypia in squamous cells, high- } \\
\text { grade intraepithelial lesion (comprising } \\
\text { grade II and III cervical intraepithelial } \\
\text { neoplasms) }\end{array}$ & 0 & $0.0 \%$ & 1 & $16.7 \%$ & 3 & $50.0 \%$ & 2 & $33.3 \%$ & 6 & $100.0 \%$ \\
\hline
\end{tabular}

Note: Fisher's exact test $(p<0.001)$.

Table 5 - Professional conduct according to the result of the last cervical cytopathology, São Paulo, São Paulo, Brazil, 2014

\begin{tabular}{|c|c|c|c|c|c|c|c|c|}
\hline \multirow[t]{2}{*}{ Variable } & \multicolumn{5}{|c|}{ Conduct } & conduct & \multicolumn{2}{|c|}{ Total } \\
\hline & $\mathbf{n}$ & $\%$ & $\mathbf{n}$ & $\%$ & $\mathbf{n}$ & $\%$ & $\mathbf{n}$ & $\%$ \\
\hline Result of the last cervical cytopathology & 97 & $51.1 \%$ & 78 & $41.0 \%$ & 15 & $7.9 \%$ & 190 & $100.0 \%$ \\
\hline $\begin{array}{l}\text { ASC-US: Atypical cells of undetermined significance, } \\
\text { possibly non-neoplastic, squamous }\end{array}$ & 74 & $67.9 \%$ & 21 & $19.3 \%$ & 14 & $12.8 \%$ & 109 & $100.0 \%$ \\
\hline $\begin{array}{l}\text { ASC-H: Atypical cells of undetermined significance, } \\
\text { squamous in which a high-grade lesion cannot be ruled out }\end{array}$ & 4 & $50.0 \%$ & 4 & $50.0 \%$ & 0 & $0.0 \%$ & 8 & $100.0 \%$ \\
\hline $\begin{array}{l}\text { AGC: Atypical cells of undetermined significance, possibly } \\
\text { non-neoplastic glandular cells }\end{array}$ & 10 & $45.5 \%$ & 11 & $50.0 \%$ & 1 & $4.5 \%$ & 22 & $100.0 \%$ \\
\hline $\begin{array}{l}\text { AGC: Atypical cells of undetermined significance, glandular } \\
\text { in which a high-grade lesion cannot be ruled out }\end{array}$ & 0 & $0.0 \%$ & 1 & $100.0 \%$ & 0 & $0.0 \%$ & 1 & $100.0 \%$ \\
\hline $\begin{array}{l}\text { LSIL: Squamous cell atypia, low-grade intraepithelial } \\
\text { lesion (comprising HPV cytopathic effect and grade I } \\
\text { cervical intraepithelial neoplasia) }\end{array}$ & 6 & $13.6 \%$ & 38 & $86.4 \%$ & 0 & $0.0 \%$ & 44 & $100.0 \%$ \\
\hline $\begin{array}{l}\text { HSIL: Atypia in squamous cells, high-grade intraepithelial } \\
\text { lesion (comprising grade II and III cervical intraepithelial } \\
\text { neoplasms) }\end{array}$ & 3 & $50.0 \%$ & 3 & $50.0 \%$ & 0 & $0.0 \%$ & 6 & $100.0 \%$ \\
\hline
\end{tabular}

Note: Fisher's exact test $(p<0.001)$; HPV - Human Papillomavirus.

\section{DISCUSSION}

Currently, at Unified Health Services (SUS), cervical cancer prevention and control actions are structured at BHU and in the organized incorporation of cytopathology, histopathology and specialized hospitals. These actions are monitored by the Cervical Cancer Information System (SISCOLO), which still does not allow identification of the number of women examined, but only the number of tests performed and data on colposcopy and biopsy results ${ }^{(12)}$.

The Cervical Cancer Care Line has the purpose of ensuring women humanized and integral access to qualified actions and services. These actions must be organized based on some guidelines, among them: Prevention and early detection, National
Cytology Quality Program, Access to diagnostic confirmation, Adequate and timely treatment ${ }^{(13)}$.

In Brazil, the distinct economic-cultural, regional and even intra-urban characteristics found are capable of generating a pattern in which factors related to poverty and development coexist ${ }^{(14)}$.

A study by the State University of Campinas revealed that the marital status was the only variable that showed a significant association with the performance of oncotic cytology, similar to the findings of other studies according to which married women or partners have a higher prevalence in the examination compared to those without a partner. This result may indicate that women consider it necessary to have Pap smears only in situations of active sexual life ${ }^{(15)}$.

It is noteworthy that women were equally assisted in both traditional and FHS models $(p=0.320)$. Thus, the study reveals 
that the fact that they were not assisted by a specialist doctor, a gynecologist, did not interfere with assistance in general, that is, general practitioners and nurses were able to provide equal care for women with changes in cytopathological examination.

It was shown that just over $30 \%$ of women attended medical and nursing consultations once a year; result below expectations, since, depending on the result of the atypia presented, this frequency should be higher. Thus, if the woman had atypia ASC-US and LSIL, she should return to the consultation in six months for a new collection of oncotic cytology. In the atypias ASC-H, AGC and HSIL, their return should occur in a maximum of three months for the evaluation of the colposcopy result, a fact that hardly occurred.

The Brazilian guidelines are clear when determining the period of three months for the referral to the unit where the cytopathological examination was performed, until the colposcopy was obtained by women up to 20 years old, with a report of high-grade intraepithelial lesion (HSIL) and of immediate colposcopy for cases of High-Grade Intraepithelial Lesion, which cannot exclude microinvasion or invasive squamous cell carcinoma (ASC-H). On the other hand, a three-year periodicity is recommended after two negative annual controls ${ }^{(11)}$.

It is important to note that colposcopy is not a cervical cancer screening tool, but it is an essential test for clarifying abnormal Pap test results ${ }^{(16)}$.

The time between the exam and the result at the $\mathrm{BHU}$ was 27.1 days. This interval is noticeable considering that it is similar in all basic health units in the city of São Paulo. The average time between the exam and the return visit to obtain the result was 10.5 months. This fact leads to the question that problems in the quality of the collection procedures, in the agility of the results and in the timely treatment of lesions, often resulting from deficiencies in the structure and work process of the Primary Care services, may have a negative impact on the occurrence of cervical cancer ${ }^{(17)}$. In this sense, the interventions used to implement cervical cancer prevention programs include the use of a case manager, telephone contact, invitation letter, educational activities, dissemination in the media, community health agents and partnerships. All of these actions have positive results in increasing the participation of women and are of low financial cost ${ }^{(18)}$.

The data revealed that, in $51.1 \%$ of women, the professional's conduct was adequate after the result of the last cervical cytopathology. However, it still stands out that, in $41 \%$, the conduct was not adequate, and $7.9 \%$ did not have any type of conduct. Considering that primary care assistance aims at the prevention and control of cervical cancer with the aim of early diagnosis and reduction of morbimortality, inappropriate conducts need to be revised, as they can cause inefficiency in the public health system and irrational use of resources with low resolution.

Such results are similar to those obtained in the cross-sectional study in the women's health care network focused on the diagnosis of cervical cancer in the health micro region of Nova Andradina, Mato Grosso do Sul, where there was non-conformity between test results and interventions. In 78\% of low-grade non-neoplastic lesions, women were referred to Secondary Care services, and $21 \%$ of those with lesions that should be referred were treated at the primary level. This result demonstrates a lack of communication between points of care, such as Primary Care as a gateway, followed by medium and high complexity, equipment of different technological densities distributed spatially and absence of reference and counter-reference protocols ${ }^{(19)}$.

When considering the group of users with ASC-US, a low-severity disease for most women, a conservative, non-invasive approach is recommended. Factors such as the woman's age and previous cytological screening should be considered in this decision. The Ministry of Health recommends starting screening for cervical cancer at age 25 for women who have already started sexual activity. After two negative exams with an annual break, the break between exams should be three years. They must continue until the age of 64 and be discontinued when, after that age, women have had at least two consecutive negative tests in the last five years ${ }^{(11)}$

On the other hand, the group of women who had LSIL received referrals, mostly (86.4\%), classified as not suitable since these women were referred primarily to medical consultation or were asked to have colposcopy. In this sense, the initial recommendation of the Cervical Cancer Screening Guidelines recommended by the Ministry of Health is that women with a cytopathological diagnosis of LSIL should repeat the cytopathological examination in six months in the Primary Care unit. Understanding the natural history of HPV infection supports the postponement of the investigation, avoiding overdiagnosis or overtreatment induced by the approach to lesions that tend to spontaneous regression. If the repeat cytology is negative in two consecutive exams, the user must return to the triennial cytological screening routine in the Primary Care unit. If any subsequent cytology is positive, it should be referred to the colposcopy referral unit ${ }^{(11)}$.

According to results obtained in the present study, of the 190 women with atypias, 44 (23.2\%) had LSIL. Of these, 6 (13.6\%) received proper conduct; and 38 (86.4\%), not adequate - according to national guidelines. It was observed that, for $35(92.1 \%)$ of these, there was a request for colposcopy, and 24 (68.6\%) performed it. Regarding the final outcome after analyzing the results of these 44 women, $12(27.3 \%)$ returned to the annual gynecological routine, $26(59.0 \%)$ to the semester, only $1(2.3 \%)$ was referred to high risk due to atypia complication and, finally, $5(11.4 \%)$ abandoned the treatment (Tables 1 and 4).

Women with ASC-H or LSIL, on the other hand, had the highest percentage (above 59\%) of follow-up of the semi-annual gynecological routine. Likewise, women with HSIL had the highest percentage (50\%), compared to other women, of being referred for treatment at high risk (Table 4). Recalling that all women with ASC-H cytopathological report should be referred to the secondary unit for colposcopy, after which it should be considered whether it is satisfactory or unsatisfactory. For women in whom the test is satisfactory and without colposcopic changes, a new cytology should be obtained in six months, in the secondary unit, and the return to the primary unit should occur after two consecutive negative cytologies ${ }^{(11)}$.

It is known that all women who present cytology suggestive of a high-grade lesion (HSIL), in the Primary Care Unit, should be referred to the Secondary Reference Unit for colposcopy 
within three months after the result. The repetition of cytology is unacceptable as an initial conduct ${ }^{(11)}$.

It highlights the relevance of the Brazilian guideline for cervical cancer screening, which aims to disseminate evidence-based recommendations to guide health professionals' decision-making and promote the safety and quality of care offered to women. Thus, assistance in Primary Care, carried out by health professionals, doctors and nurses, can directly interfere with efficiency, resolving capacity and adequate use of resources destined to assistance programs and protocols in public health services based on the best scientific evidence.

\section{Study limitations}

The lack of previous research on the topic addressed presented itself as one of the limitations of the study, but it provided an opportunity to identify new gaps in the literature and, consequently, new investigations.

\section{Contributions to the field of Nursing}

The result of this study may serve as a basis for future studies in this area, as well as contributing to the promotion of safety and quality of care offered to women assisted in Primary Care.

\section{CONCLUSIONS}

The results of this study show the need to improve the screening program and correctly target cell atypias of the cervix, aiming to guarantee the referral and access of the target population for the diagnostic investigation and treatment of precursor lesions, when indicated, which contribute to the rational use of financial resources for health. The importance of humanized care by the professionals who perform the welcoming of women is emphasized, who should not be judged as passive social subjects, since they have unique values and have the power to decide on their respective bodies.

\section{REFERENCES}

1. World Health Organization (WHO). Cancer [Internet]. 2017 [cited 2017 Sep 21]. Available from: http://www.who.int/mediacentre/factsheets/fs297/en

2. Ministério da Saúde (BR). Instituto Nacional de Câncer José Alencar Gomes da Silva (INCA). Incidência de câncer no Brasil. Estimativa 2018[Internet]. Rio de Janeiro: INCA; 2018[cited 2017 Sep 21]. Available from: https://www.inca.gov.br/publicacoes/livros/ estimativa-2018-incidencia-de-cancer-no-brasil

3. Carvalho PG, O'Dwer G, Rodrigues NCP. Health assistance path of women between diagnosis and treatment initiation for cervix cancer. Saúde Debate. 2018;42(118):687-701. doi: 10.1590/0103-1104201811812

4. Instituto Nacional do Câncer. Incidência de Câncer no Brasil [Internet]. 2016 [cited 2016 Apr 04]. Available from: http://www.inca.gov.br/ estimativa/2016/sintese-de-resultados-comentarios.a

5. Cecil WV. Colposcopy of adenocarcinoma in situ and adenocarcinoma of the uterine cervix. In: Mayeaux EJ, Thomas Cox J, (Eds). Modern Colposcopy. Textbook and Atlas[Internet]. 3a ed. Wolters Klumer Lippincott Williams \& Wilkins; 2012[cited 2017 Sep 21]:325-7. Available from: https://www.pdfs.semanticscholar.org/7ef7/270236ab602443f9504af0a6586c76a03cff.pdf

6. Albuquerque VR, Miranda RV, Leite CA, Leite MCA. Preventive cervical cancer tests: women's knowledge. Rev Enferm UFPE [Internet]. 2016 [cited 2017 Apr 19];10(5):4208-18. Available from: https://periodicos.ufpe.br/revistas/revistaenfermagem/article/view/11165/12692

7. Instituto Nacional de Câncer. Consolidado 2014: incidência de câncer no Brasil[Internet]. Rio de Janeiro: Inca; 2014. [cited 2017 Apr 23]. Available from: http://www.inca.gov.br/estimativa/2014/sintese-de-resultados-comentarios.asp

8. Ferlay J, Soerjomataram I, Dikshit R, Eser S, Mathers C, Rebelo M, et al. Cancer incidence and mortality worldwide: sources, methods and major patterns in GLOBOCAN 2012. Int J câncer[Internet]. 2015 [cited 2017 May 17];136(5):E359-86.: Available from http:// portaldeboaspraticas.iff.fiocruz.br/wp-content/uploads/2018/04/Ferlay_et_al-2015-International_Journal_of_Cancer.pdf

9. Malta M, Cardoso LO, Bastos FI, Magnanini MMF, Silva CMFP. STROBE initiative: guidelines on reporting observational studies. Rev Saúde Pública. 2010;44(3):559-65. doi: 10.1590/\$0034-89102010000300021

10. Ministério da Saúde (BR). Instituto Nacional de Câncer José de Alencar Gomes da Silva (INCA). Nomenclatura brasileira para laudos citoplatológicos cervicais[Internet]. Rio de janeiro: INCA; 2012[cited 2017 May 17]. Available from: https://www.inca.gov.br/sites/ufu.sti.inca. local/files//media/document//nomenclatura-brasileira-para-laudos-citopatologicos-cervicais-2012.pdf

11. Ministério da Saúde (BR). Instituto Nacional do Câncer. Coordenação Geral de Ações Estratégicas. Divisão de Apoio à Rede de Atenção Oncológica. Diretrizes brasileiras para o rastreamento do câncer do colo do útero [Internet]. Rio de Janeiro: INCA; 2011 [cited 2017 May 17]. Available from: http://www.bvsms.saude.gov.br/bvs/publicacoes/inca/rastreamento_cancer_colo_utero.pdf

12. Vale DBAP, Morais SS, Pimenta AL, Zeferino LC. Assessment of the cervical cancer screening in the Family Health Strategy in Amparo, São Paulo, Brasil. Cad Saúde Pública. 2010;26(2):383-90. doi: 10.1590/S0102-311X2010000200017

13. Ministério da Saúde (BR). Secretaria de Atenção à saúde. Departamento de Atenção Básica. Caderno de Atenção Básica. Controle dos Cânceres do Colo de Útero e Mama [Internet]. 2a ed. 2013[cited 2017 May 17]. Brasília-DF. Available from: http://www.bvsms.saude.gov.br/ bvs/publicacoes/controle_canceres_colo_utero_2013.pdf

14. Rodrigues AD, Bustamante TMT. Breast cancer and cervical cancer mortality trends in a medium-sized city in Southern Brazil, $1980-2006$. Cad Saúde Pública. 2011;27(2):241-8. doi: 10.1590/S0102-311X2011000200005 
15. Amorim VMSL, Barros MBA. Equity of access to Pap smears: population-based study in Campinas, São Paulo, Brazil. Rev Bras Epidemiol. 2014;17(Suppl 2):136-49. doi: 10.1590/1809-4503201400060012

16. Sharp LC, Cotton S, Cruickshank M, Gray N, Neal K, Rothnie K, et al. Long-term worries after colposcopy: which women are at increased risk? Womens Health Issues. 2015;25(5):517-27. doi:10.1016/j.whi.2015.04.002

17. Tomasi E, Oliveira TF, Fernandes PAA, Thumé E, Silveira DS, Siqueira FV, et al. Structure and work process in the prevention of cervical cancer in Health Basic Attention in Brazil: Program for the Improvement of Access and Quality. Rev Bras Saude Matern Infant. 2015;15(2):171-80. doi: 10.1590/S1519-38292015000200003

18. Soares MBO, Silva SR. Interventions that facilitate adherence to Pap smear exam: integrative review. Rev Bras Enferm. 2016;69(2):404-14. doi: 10.1590/0034-7167.2016690226i

19. Farias ACB, Barbieri AR. Follow-up uterine cervical cancer: study of continue assistance to patient in a health region. Esc Anna Nery. 2016;20(4):e20160096. doi:10.5935/1414-8145.20160096 